\title{
Material Review of the English Textbook Bahasa Inggris (2017 Revised Edition)
}

\author{
Ria Wulandari $\left.{ }^{1 *}\right)$, Tahrun $^{2}$, Mulyadi $^{2}$
}

\author{
${ }^{1}$ SMP Negeri 1 Lawang Wetan \\ ${ }^{2}$ Universitas PGRI Palembang, Indonesia \\ *Corresponding author. Email: riaw371@gmail.com
}

\begin{abstract}
This study aims at finding out and analyze if Bahasa Inggris textbook for Grade XI fulfill Badan Standar Nasional Pendidikan (BSNP) textbook evaluation criteria and the degree to which English textbook reflects the competencies Curriculum 2013. The study design included in this analysis is a qualitative descriptive analysis. Data Sources "Bahasa Inggris" textbooks, curriculum 2013 Literary works applied for Second Year Students of Senior High School and Vocational Students. The author was using the documents in the collection of data derived from the 2013 curriculum content for the eleventh grade of high school and the Rubric evaluation by BSNP. The textbook entitled Bahasa Inggris gained 94\% for content feasibility, $89 \%$ for feasibility of presentation, and $98 \%$ for graphic aspect. The average of the number was $94 \%$. It means that the textbook was fulfill the textbook evaluation criteria and reflected the competencies of Curriculum 2013.
\end{abstract}

Keywords: Material Review, Textbook, Curriculum 2013

\section{INTRODUCTION}

There are many factors that affect the success of the English education process. Each of them is the training aid. Study aids can be categorized in a variety of ways, Chao [1] claimed that there are many forms of learning aid that can be easily used for learning activities, such as non-projected media (realia, model, graphics, display), projected media (OHT, slide, opaque), film, computer-based media (computer-assisted instruction, computer-controlled instruction) and multimedia kits. While there are many kinds of learning aids that facilitate learning activities, many schools still use a large number of textbooks and resources.

The textbook is one of the most critical tools for learning and teaching. According to Cunningsworth [2] the textbook is a book that contains a material summary of a particular topic or course, which has been systematically organized and chosen on the basis of a specific intent, learning orientation and student development for assimilation. The textbook is designed to help the teaching - learning activities.

Textbook is the best instrument which contains material description about particular subject and arranges systematically to give big impact toward learning success in the class. In making a good textbook, there are many aspects/rules should be considered. Because of many rules and criteria that need to be concerned in making a textbook, so that Education National Standard Council (BSNP) was made. Government Regulation No. 32 (2013, chapter 43) explained that the appropriateness of content, language, presentation, and graphics of textbook are examined/ evaluated by BSNP or team that is made by Ministry and then stated by Ministry Regulation. It means that all textbooks cannot be published before passing evaluation from BSNP. In order to be able to follow sophisticated era, BSNP always does improvement toward its criteria for assessment.

It is likely that the textbook will play a significant role in the education system in Indonesia. According to Ferris and Hedgcock [3], textbooks have a critical role to play in language contexts around the world.

According to Heinich [4] the textbooks are so common in the world in education systems. After all, textbooks are the foundation of the courses that many teachers instruct. The textbook must be consistent with the existing curriculum, the school curriculum and the expectations of the student, as well as the objectives and objectives of teaching.

The Curriculum 2013 has now been organized by the government. That's a functional program that is developed and practiced by every school in Indonesia. The Curriculum 2013 was simply a revised edition of the school curriculum. On the basis of the KTSP, design Guidelines issued by BSNP in 
2006, the School-based Curriculum was developed on the basis of the philosophy that every school in Indonesia deserves to manage its own competence on the basis of its teachers' and learners' skills and local potential sources and deserves to manage its own curriculum on the basis of the content standard provided by BSNP.

Besides then curriculum, then textbook is also the most important tool in teaching and learning process. It is the material needed by the teachers and the students in teaching and learning process. Margono [5] states that materials can be in the form of a workbook, a cassette, a CD-Rom, a video, a photocopied handout, a newspaper, a paragraph written on a whiteboard: anything which presents or informs about the language being learned, and also a textbook.

Students are expected to be creative and active. By providing a good textbook, students are expected to gain much knowledge. Unfortunately, this expectation cannot be reached because expectation does not suit with the reality. Based on the above matters, the researcher interested in conducting a research entitled "Content Analysis of English Textbook Entitled Material Review of the English textbook Curriculum (2017 Revised Edition)". The purpose of this research is to know the suitability of the textbook, so that all people concerned with education can know whether or not this book is suitable for use. While this version is released by the Ministry of Education and Culture, there is no assurance that the content in this textbook will be applicable to BSNP's assessment of standards and criteria. As a result, the researcher agreed to perform a content review on the textbook.

\section{METHODS}

This research used descriptive qualitative research design. Characteristic of the data in qualitative research is that the data is collected in the form of sentences, images, behavior not in numbers or statistical data [6]. It is aimed to analyze textbook which was in documents' form by describing the content based on criteria of BSNP. Moleong [7] said "Descriptive research refers to an analysis that provides a representation of a phenomenon or intervention.

The power of data analysis basically derived from its inductive approach, its focus on particular situations or persons, and its reliance on words rather than numbers [8]. This indicates that the information in this study is examined in the context of a summary and identification or interpretation of the texts.

The whole research studied as qualitative qualitative approach, in particular curriculum literature review. Literature review is indeed a tool to analyze qualitative data. It's indeed relevant to different research, such literature courses, that are concerned with the analysis of the content of such subjects through category, apportionment and analysis. Data Collection may be used as a tool to define relevant trends or categories of cultural content to be studied in the key texts of the research. The material may be phrases, images, concepts, concepts and also any meanings which are intended to be transmitted, as well as the content may be published, visual speech act types which appear in the form of interaction, including texts, photographs, movies and records [9].

To describe the Curriculum textbook not only undertaken using BSNP criteria but also the methods of content analysis. Text analysis is described as a research technique that used a collection of protocols for figure out the meaning of records, conceptions or textbooks. Tavakoli [10] has stated that the content review would identify the meaning of text, image and other expressions. The author was using a guideline to complete this process and then used a descriptive approach to interpret the result. Numerous researchers in the assessment of the textbook have agreed that the checklist is a robust method for evaluating and analyzing the curriculum [11].

Doing this study, the author was using the data collection technique. First move is to read and understand the contents of the English curriculum. The second step is to classify the content in each chapter of the English curriculum. Then, analyzing the data which are found. The researcher used content standard of BSNP to analyze data to know if it fulfills textbook evaluation criteria. Then, scoring criteria and percentage calculation were used.

1 Process of the analysis text based on standard/category which have made.

2 Calculating the percentage of each aspects by this formulation below:

$$
P \%=\frac{\sum q}{\sum r} X 100 \%
$$

$\mathrm{P}=$ The ratio that is obtained for each feature is examined

$\mathrm{q}=$ The mean value obtained at each feature is examined.

$\mathrm{R}=$ The highest possible rating by each feature is examined.

The above formula used to explain the outcomes of the data analysis. The score of categories used by the researcher was adapted from four scoring categories of Muniroh. 


\section{RESULTS AND DISCUSSION}

\section{1) Contents Fulfillment for BSNP}

In this study, there were three majors are used to analyze the English textbook entitled Bahasa Inggris (2017 Revised Edition), namely: (1) content feasibility which covers (a) acceptability of products with core competencies and core competencies; (b) product consistency; (c) supportive study guides; (2) presentation viability that includes (a) demonstration method; (b) education - learning methodology; (c) presentation completeness; and (3) graphics that deal with (a) book size; (b) template coverage; and (c) content design. Analysis findings were described as follows.

Materials relevance to standard and basic competence was categorized as very good category, because there are interpersonal and transactional texts such as offers and suggestions expressions in making, accepting, and declining both of them and giving opinions/ thoughts expressions. Accuracy of the materials was categorized as very good category, because the social function in chapter 3 is not suitable with social function in lesson plan. Supporting materials of learning was categorized as very good category, because teaching materials are taken from relevant and trusty source. This evaluation sub-aspect is deserved to gain perfect score because there are many activities in this textbook which purposed to make students help, tolerance, and appreciate each other.

Technique of presentation was categorized as very good category, because materials in this textbook presented in text form and also have consisted of introduction, content, and closing. Presentation of learning was categorized as very good category, because material presentation has made students interact/communicate in English with their teacher and environment. The textbook makes students more creative and independent by doing all the tasks by themselves.

Completeness of presentation was categorized as good category, because of three items named summary and reflection, glossary, and index did not exist in the textbook. In the meantime, the key points of the subject must be included in each chapter of the textbook and the reflection must be terminated in each unit of the textbook. It then required the glossary of important terminology within the document, followed by a summary of the meaning of those terminology which are listed alphabetically. The last one was the index (subjects and authors). It was a list of essential words accompanied by a page number of their appearance. A list of writers whose works are included in the materials followed by a page number for each reference.
Size of book / format of book was categorized as very good category, because paper size of the textbook is A4 which is categorized suitable toward ISO standard. The paper size is fit toward textbook's content material as well. Cover design was classified as a very good category because the composition of the layout feature (title, author, illustration, logo, etc.) is matched with the layout of the text.

The font size of textbook title is the biggest than author and publisher name which means good. Another key to remember, the color of the textbook title (yellow) is contrast with background color (dark blue). The textbook title does not use decorative letters, so the students do not find difficulty to read the title. Content design was categorized as very good category, because there were two items did not appropriate in the textbook.

\section{2) Reflection for Curriculum 2013 Competencies}

There were nine core competencies in the Curriculum 2013 syllabus, which included providing and asking for information on suggestions and offers, providing and requesting information on opinions and thoughts, an official invitation to provide and request information on school/workplace activities, formal oral and written invitations, school/workplace activities, a personal letter by giving and receiving information related to the activities of oneself and those around them, to provide and ask for information on causal relationships, to clarify texts by providing and asking for information on sociological symptoms, to describe the social roles and linguistic elements of life-related song lyrics.

The basic competencies of the English textbook mirrored all the basic competencies of the syllabus. It is shown in the table of relevance of each object.

Based on the data got through the instrument reveals that English textbook entitled Bahasa Inggris got $94 \%$ for the total average of all items. It shown that this book was quite perfect but there were some items which was not provide in the textbook.

In terms of content feasibility, the suitability of materials with core competencies and core competencies, material accuracy, and support for learning materials were three sub-aspects. Interpersonal and transactional texts in this textbook are followed by interesting activity to develop students' skill like speaking, reading, and writing. In short functional text, there are formal invitation, personal (informal) letter. In monologue text, there are exposition and explanation text. The dominant material in the textbook is reading which is less flexible and not balance toward other material skills.

Listening material is only in chapter 7 because at this chapter students should figure out a song's meaning by reading the song's lyrics while listen to 
the song. Another weakness is incomplete materials in chapter three and five. In formative assessment part, there is sentence states that students can tell the difference between formal and informal invitation in chapter three likewise in chapter five (distinguish informal and formal letter) whereas textbook only provides formal invitation (chapter three) and personal/informal letter (chapter five) material. It will be better if the material about letter combines in one chapter, to make students easy to distinguish between formal and informal letter.

For the sub-aspects named accuracy of the materials gained $96 \%$, because the social function in chapter 3 is not suitable with social function in lesson plan. In lesson plan, the social function is to maintain interpersonal relationship in formal context. It is contrast with social function states in book which is to invite people to formal and social events. In social function, offers and suggestions expressions are functioned to facilitate interpersonal communication between different people (interpersonal and transactional communication), while exposition which functioned to persuade/ argue something/someone and explanation functioned to describe how or why things happen (functional communication). In element and meaning structure, offers and suggestions expressions. In linguistics features, the textbook has fulfilled the aspects.

Feasibility of presentation got the lowest score because there were items did not exist. Completeness of presentation was categorized as good category, because of three reasons. Firstly, in the content part the textbook does not provide materials' resume or summary at the end of each chapter. Summary is the main concept of the chapter in question, which is laid out in simple, succinct sentences and makes it easier for students to understand the full substance of the chapter and the learning experiences they have experienced.

This textbook also does not provide reflection. It is needed to have reflection because it contains of conclusions and behaviors that must be emulated by students. Then, in the closing part the textbook does not provide glossary and index. It makes students as beginner learners are difficult to find out information. Meanwhile, in introduction part, the aspects have done well, there is table content and preface provided. In content part, all the aspects are good.

Graphic aspect which was important to evaluate, especially about content design. There was different margin from each part/ chapter/ sub-chapter which is identified less harmonious. In addition, in terms of material typography, which does not use too many fonts required, no more than two types of letters must be used to prevent students from absorbing the information conveyed. But there were decorative letters in chapter three about examples of formal invitation letter. It makes students difficult to read and understand the content/ message of letter.

The last was discussion about appropriateness of the syllabus used in Curriculum 2013 with the textbook. The result was the basic competencies of the material in English textbook entitled Bahasa Inggris and the syllabus were exactly similar. It means that it was reflected $100 \%$.

\section{CONCLUSION}

In accordance with the previous chapters, the writer draws conclusions on: (1) fulfillment of Badan Standar Nasional Pendidikan (BSNP) textbook evaluation criteria, and (2) reflection for the Curriculum 2013 competencies. They were stated as follows: (1) fulfillment of Badan Standar Nasional Pendidikan (BSNP) Textbook Evaluation Criteria. In this study, Bahasa Inggris textbook for Grade XI fulfill BSNP textbook evaluation criteria. The textbook entitled Bahasa Inggris gained 94\% for content feasibility, $89 \%$ for feasibility of presentation, and $98 \%$ for graphic aspect. The average of the number was $94 \%$. It means that the textbook was fulfill the textbook evaluation criteria based on content standard of BSNP and categorized as very good, and (2) reflection for the Curriculum 2013 Competencies. In this case, all items in basic competencies in the syllabus of Curriculum 2013 consisted in the textbook. Moreover, English textbook entitled Bahasa Inggris was $100 \%$ reflected the competencies Curriculum 2013.

\section{ACKNOWLEDGMENTS}

Our deepest gratitude goes to Teachers in SMP Negeri 1 Lawang Wetan, Chancellor of Palembang PGRI University, Director of the Postgraduate Program of PGRI Palembang University and the Education Management Study Program of PGRI Palembang University, who have supported us in doing this extraordinary thing. This project is funded independently. We also want to thank our Education Management friends who helped us a lot in a short time frame to complete this project.

\section{REFERENCES}

[1] Chao, T. (2011). The hidden curriculum of cultural content in internationally published ELT textbooks: A closer look at New American inside out. The Journal of Asia TEFL, 8(2), 189210.

[2] Cunningsworth, A. (1995). Choosing your coursebook. London: Macmillan Heinemann. 
[3] Ferris, D., \& Hedgcock, J. S. (2005). Teaching ESL Composition: Purpose, Process, and Practice. USA: Laurence Elbaum Associates.

[4] Heinich, R. et al. (2007). Instructional Technology and Media for Learning. Ohio: Pearson Merrill Prentice-Hall.

[5] Margono, S. (2014). Metodologi Penelitian Pendidikan: Komponen MKDK Cetakan 9 [Educational Research Methodology: Molded MKDK Components 9]. Jakarta: Rineka Cipta.

[6] Maxwell, J., A. (1996). Qualitative Research Design. London: SAGE Publication.

[7] Moleong, L. J. (2011). Metodelogi Penelitian Kualitatif [Qualitative Research Methodology]. Bandung: Remaja Rosda Karya.

[8] Muslich, M. (2010). Textbook Writing, Dasardasar Pemahaman, Penulisan dan Pemakaian Buku Teks [Textbook Writing, Basics of Understanding, Writing and Using Textbooks]. Jogjakarta: Ar-Ruzz Media.

[9] Razmjoo, S.A. (2007). High schools or private institutes textbooks? Which fulfill communicative language teaching principles in the Iranian context? Asian EFL Journal 9(4).

[10] Tavakoli, H. (2012). A Dictionary of Research Methodology and Statistics in Applied Linguistics. Tehran: Rahnama Press.

[11] Tomlinson, B. (1998). Materials Development in Language Teaching. United Kingdom: Cambridge University Press. 